\title{
The Geopolitics of Emilia Pardo Bazán's La Quimera: Femme Fatale as Split Feminist Subject
}

\author{
Marina Cuzovic-Severn \\ Assistant Professor of Spanish \\ Department of Foreign Languages and Literatures \\ University of Alaska Fairbanks, Fairbanks, AK, USA
}

Doi: $10.1515 / \mathrm{mjss}-2017-0021$

\section{Abstract}

This paper analyzes the representation of the femme fatale in Emilia Pardo Bazán's La Quimera (1905). Femme fatale is described by many critics as an expression of masculine anxieties and fears, caused by political crisis and growth of feminine independence in the nineteenth century. Male authors employed this figure to preserve patriarchal structure and the existent power balance between prescribed gender roles. I argue that Pardo Bazán, through imitation of male writers and manipulation of hidden meanings in La Quimera, employs this masculinist projection to express latent feminist ideas and a critique of the contemporary social position of women. In her novel, Pardo Bazán creates a feminist femme fatale and, through her geopolitically split formation (France/Latin America/Spain), criticizes Spanish patriarchy, domesticity and non-modernity. She achieves this without overtly violating masculine narrative structure or demeaning patriarchal order, as she appropriates the originally masculinist imagery of fatal woman. Nevertheless, the eventual fate of Pardo Bazán's femme fatale-especially the elaboration of internal dialogs and her presentation not as antagonist and invasive Other but as protagonist and subjectdemonstrates fundamental differences of a feminist perspective within her elaboration of this masculine fantasy. In this way, in a time and space where feminism as a movement did not yet exist or was in its formative years, Pardo Bazán immensely contributed to the development of European/Spanish feminist thought.

Keywords: Emilia Pardo Bazán, femme fatale, geopolitics, feminism, imperialism

\section{Introduction}

Robert E. Osborne (1964) comments that the main difference between Emilia Pardo Bazán's last three novels_La Quimera (1905), La Sirena negra (1908) and Dulce dueño (1911)—and the rest of her works is "la penetración psicológica, o, mejor dicho, el esfuerzo por parte de ella de profundizar en lo más íntimo de sus creaciones artísticas" (p. 116). Many critics, such as Mariano López (1979), Walter T. Pattison (1971) and Francisca González-Arias (1992), see La Quimera as Pardo Bazán's most important work of fiction. Eduardo Gómez de Baquero (1926), describes it as "la más perfecta de sus novelas como composición artística y como riqueza de elementos" (p. 156).

I agree with Osborne and I further suggest that these last three novels-all showcasing femmes fatales - offer the culmination of the portrayal of independent women and most directly (yet still surreptitiously) express Pardo Bazán's feminist ideas. I would also add that in addition to being the most perfect artistically, La Quimera is also Pardo Bazán's work in which her manipulation of meaning reaches its peak.

Seemingly, the focus of the work is on the depiction of the malady of modern man (GonzálezArias, 1992, p. 196) and a critique of modernity through the portrayal of the physical and moral 
deterioration of the femme fatale Espina Poncel. However, in La Quimera and other two novels with femmes fatales, Pardo Bazán positions her female protagonists as subjects who have their own voices and principles. All three works have a geopolitical component-France (La Quimera), Britain (La Sirena), Mexico and Egypt (Dulce dueño)—which facilitates her protagonists' individual and feminist acting. Ultimately, the femmes fatales all end up in non-geopolitical or metaphysical spaces-drugs, death or madhouse - that may liberate them from male influence but at the same time destroy them. Thus, Pardo Bazán's main feminist strategy, the geopolitical split, at the same time reflects the limit of her feminism in the patriarchal Spain of Restoration. Still, these three novels offer critique of the Spanish backwardness and limitations imposed over women and, in that way, contribute to the improvement of their position.

It is a goal of this article to identify the feminist strategies in La Quimera and to describe Pardo Bazán's ways of making them invisible to patriarchal critics, while transmitting them to her female readers.

\section{Women Writers on the Margins of Contemporary Movements}

At the turn of the twentieth century, female writers' novels were marginalized and not considered part of the official literary canon. Alda Blanco (1995) comments that, during the nineteenth century, men were the ones who created art, whereas women were the ones who passionately re-created, or imitated (p. 124). A further problem was, as Blanco explains, that Spanish women did not imitate the creativity of only Spanish male writers, but also of French male writers. This constituted a political issue, because it was perceived as the acceptance and internalization of French cultural superiority and the dependence of Spain on France (Blanco, 1995, p. 124).

Blanco further observes how the construction of the literary canon reflected the construction of the Spanish nation: "The canon was being constructed in much the same way that a nation is constructed; where borders are imagined, drawn, and subsequently policed in order to protect national security from outside elements" (p. 125). This explains why a majority of women writers were excluded from the canon and were seen as impeding the development of a national literature, and with this, national identity.

Pardo Bazán was among the few women writers who were not excluded from the canon and whose feminine writing was "acceptable" for the male-centered society. She demonstrated with her works that female authors were capable of writing like men and, beyond this, expressing their feminist ideas without violating masculine narrative structure. As observed by Geraldine Scanlon (1995), Pardo Bazán demonstrated:

an acute awareness of the ways in which gender identity was structured and, although she frequently employed the conventional positive/negative associations of terms such as varonil/femenil [manly/womanly], she saw no reason why women should not appropriate the virtues traditionally ascribed to men. (p. 231)

Ultimately, Pardo Bazán's works were part of the canon, despite the criticism of her male contemporaries, because she wrote realist fiction that reflected national matters:

[She] chose to share the male literary terrain by writing 'realist' fiction.... Although her contemporaries were very unsympathetic towards her person and her literary production-if not downright nasty-they could not silence her voice given that she shared their project of a Spanish realist novel which, at least in theory, reflected and spoke to the nation as a whole. (Blanco, 1995, p. 133, emphasis added)

I agree with Blanco's conclusion that Pardo Bazán's works correspond to the contemporary masculine paradigm of novelistic creation and I employ this position as a starting point for my analysis of La Quimera. I add that, although La Quimera seemingly reiterates masculine novelistic paradigms, with it Pardo Bazán transmits feminist ideas for the improvement of women's social position in a more daring way than any other Spanish female author before. 


\section{The Femme Fatale and her Dual Uses}

On a superficial level, La Quimera propagates patriarchal values, but it also references the current geopolitical situation and reflects the crisis of Spanish imperial-national identity. Geopolitics was an important element of the discourse of nationalism at the end of the nineteenth and beginning of the twentieth centuries, as many European ex-empires, like Spain and France, tried to recover and reestablish their superiority one over another. Lorenzo López Trigal and Paz Benito Del Pozo (1999) explain geopolitics as "el estudio de la influencia del espacio geográfico sobre los estados y su política. Con frecuencia se identifica con la geografía política, de más amplio contenido" (p. 283).

An important tool for the expression of geopolitical tensions in literature of the late nineteenth century was the figure of femme fatale. The femme fatale is described as a masculine projection and expression of masculine anxieties and fears, caused by colonial loss, political crisis and growth of feminine independence by several feminist authors, such as Rebecca Stott (1992), Julie Grossman (2009), Mary Ann Doane (1991), and Helene Hanson and Catherine O' Rawe (2010).

In the works of male authors in the nineteenth century, such as Prosper Mérimée's ${ }^{1}$ Carmen (1845) and Ramón del Valle-Inclán's La Sonata de estío (1903), patriarchal power structures express their imperialist anxieties ${ }^{2}$ by raising the seductive yet destructive persona of a geopolitically split femme fatale (e.g. a Spanish Gypsy in Carmen), then sanction and punish such "immoral" feminine behavior. In this way, patriarchal structures preserve the existent power balance between both gender roles and nations ${ }^{3}$.

This is why male writers, including Mérimée and Valle-Inclán, represent their femmes fatales as exotic, seductive and dangerous women. Such women challenge patriarchal order, echo the crisis of the Spanish national and imperial identity, and so must end up domesticated or murdered by Spanish men. In Carmen, the exotic, irresistible Gypsy Carmen is murdered by a seduced and manipulated Spanish man. In Sonata the indigenous femme fatale, Niña Chole, is domesticated and subordinated by a noble Spaniard.

In the works of women authors, like Pardo Bazán's novels and Fernán Caballero's La Gaviota (1849), male narrative fantasy is imitated but the figure of femme fatale is used as a performative strategy for expression not of restorative, masculinist messages, but of subversive, feminist ones.

As commented by Noël Valis (1995), such textual manipulation, which allows "reading between the lines" is possible because women and men read and identify with the characters in different ways (p. 48). Rita Felski (2003) also elaborates on textual manipulations in women's writing and states that "the true meaning of women's writing lies beneath the surface, in covert messages and submerged clues. Because this meaning is socially unacceptable and even subversive, it is buried deep within the text" (p. 69).

Such surreptitious textual manipulations and maneuvers, on the part of women authors, were necessary because, although strong and opinionated female figures, women writers in the nineteenth and the beginning of the twentieth centuries, including Pardo Bazán, Fernán Caballero, María del Pilar Sinués de Marco, Faustina Sáez de Melgar and Angela Grassi, lived in a patriarchal society that above all saw them as mothers and housewives. Because of this position, they had to protect themselves from the condemnation and restrictions that their exceptional professional status could have provoked.

\footnotetext{
${ }^{1}$ According to Joseba Gabilondo (2008), Virginia M. Allen (1979) and Elena Baynat Monreal (2007), Carmen is the first European femme fatale. Therefore, the original representation of the femme fatale in Europe is a masculine creation.

${ }^{2}$ The femme fatale in the two mentioned male authors' works (Carmen and Sonata de estio) is related to the colonies. In the former work, she is a Gypsy and, in the latter, a Latin American seductress. Domination of the fatal woman in these works reflects domination over the Other and symbolic recuperation of imperial power and masculine hegemony.

${ }^{3}$ See Edward Said's Orientalism (1978) for a discussion of the relation between the dichotomies masculinefeminine and Occident-Other/Orient.
} 


\title{
3.1 Reproduced Characteristics of the Femme Fatale
}

In La Quimera, Pardo Bazán creates a feminist female character-femme fatale Espina- without supplanting masculine narrative structure and thereby overtly challenging patriarchal order. She achieves this through portrayal of a half-Spanish, half-foreign (geopolitically split) femme fatale, whose appearance, actions and destiny comply with the canonical representation of the fatal woman in male authors' works. In this way, Pardo Bazán avoids ostracism and marginalization by male critics and colleagues.

Espina's character is created in accordance with an established, masculine image of the femme fatale-she is an irresistible, unattainable seductress who uses men for achieving personal goals. Like a canonical femme fatale, Espina has many suitors or "victims" in the novel. Her boyfriend, Brazilian Valdivia, is a man obsessed with her and tortured with terrible jealousy caused by her previous adulteries: "Ella misma-no podía ser nadie más-había provocado los tardíos celos de Valdivia, para robarle la protección eficaz del brasileño" (Pardo Bazán, 1991, p. 447). The fact that her boyfriend is non-Spanish, American, also has a geopolitical value, as it testifies to Espina's transatlantic powers of seduction.

Like Carmen and Niña Chole, Espina is also a seductress who uses her beauty and talents to achieve social and personal goals. This likewise puts men into challenging situations. For Silvio, a Spanish artist, the main protagonist of the novel and Espina's main "victim", Espina is the culmination of elegance, form and physical beauty. She inspires him and provokes his artistic creativity-she is his muse and aesthetic ideal, but at the same time, an epitome of evil:

\begin{abstract}
Espina me atrae, tal vez por el sumo refinamiento de su existencia y la desdeñosa altanería con que prescinde de las nociones admitidas y vulgaronas...para Espina no existe nada fuera de lo bonito y lo selecto, de ese aquilatamiento sensual de la exterioridad, que hace de ella una especie de Cleopatra...probablemente me atrae Espina porque es exaltadamente elegante y rematadamente mala. (Pardo Bazán, 1991, p. 358)
\end{abstract}

Jennifer J. Wood (1990) comments that Espina's comparison to Cleopatra by Silvio captures the essence of feminine perfidy and perversity that she embodies ( $p$. 4). In addition, this comparison enhances Espina's characterization as femme fatale, as Cleopatra is considered one of its most prolific prototypes.

Espina's mechanisms of control over men are also reproduced from male author's presentations of femme fatale (Carmen and Sonata) and testify to her cruelty and lack of emotion. Espina only brings Silvio to Paris to humiliate him and make the Brazilian Valdivia jealous, but under the pretense that she will help him establish himself as an artist: "Con calculo pérfido, había traído a Silvio a Paris prematuramente, a fin de hacerle regresar a Madrid avergonzado" (Pardo Bazán, 1991, p. 447). The situation ends up being a sadistic game of torture and humiliation of Silvio that eventually destroys him. Espina makes Silvio spend his newly earned money on her caprices and publicly embarrasses him on several occasions. Silvio's reactions are always very strong but he, although aware of Espina's sadism and perversion, which previously attracted him, is never able to escape them:

No se acordaba Silvio de que la indiferencia moral, el desprecio a la humanidad, de Espina, le habían parecido en Madrid sello de naturaleza escogida y artística, picante atractivo de su trato y su persona... ¡Cuánto daría ahora por beber la expresión de la piedad y la generosidad en unos ojos humanos! (Pardo Bazán, 1991, p. 444)

\subsection{Aesthetics as Subjectivity from a Feminist Perspective}

Besides many similarities with male authors' imagery of femme fatale, Espina also exhibits some very important differences. Unlike male authors' femmes fatales, she is opinionated, intelligent and with a great aesthetic sensibility, all of which forms part of her presentation as a feminist subject. A femme fatale as a feminist subject is Pardo Bazán's most radical difference in comparison to male writers. 
As previously stated, Pardo Bazán's feminist subject is geopolitically split, as her liberation and subjective existence is predicated on the collision of two conflicting national projects; a woman like Espina cannot exist in traditional, patriarchal Spain. Geopolitically, Espina represents France: she is Atlantic, rich and modern. In contrast, Silvio, who represents Spain, is poor, insecure and non-modern. Exactly the opposition between modern/non-modern is what forms Silvio's irresistible desire for Espina and this is, conversely, why he rejects the Spanish ángel del hogar, Clara.

Espina and Silvio share modernist aesthetic longing, decadence, unhappiness and dissatisfaction with the ugliness and trivialities of real life, as he comments about her aestheticism: "para Espina no existe nada fuera de lo bonito y lo selecto, de ese aquilatamiento sensual de la exterioridad" (Pardo Bazán, 1991, p. 358). This longing erases the gender difference between them and makes them both subjects in their own attempts to make sense of the absurd world around them. Such characterization of femme fatale, as a subject and protagonist, differs from the one seen in male author's works, where she is presented as the object of masculine discourse and an antagonist.

Espina's ability to participate in the arts, to inspire and influence their creation, makes her an aesthetic subject, which undermines the traditional patriarchal premise that women were inferior to men in artistry, because of their natural deficiency of creative imagination (Scanlon, 1976, p. 67). According to Susan Kirkpatrick (2003), the fact that her main female character is a decadent aesthetic subject, at a time when decadentism was considered a masculine characteristic, is Pardo Bazán's answer to female subordination, expressed through representation of women as passive aesthetic subjects who are inferior to men. Kirkpatrick explains this when she says:

[La] exaltación del sujeto estético como el único agente capaz de transformar el mundo natural y material (con tanta frecuencia representado por figuras femeninas) en la realidad superior del arte y la belleza funcionaba como potente refuerzo de una diferenciación de género que codificaba la feminidad como pasiva, inferior y objeto de la mirada masculino [ángel del hogar]. (p. 93)

Through modernist longing, Espina is also presented as a subject in her own destruction. She reaches liberation from patriarchal oppression through artistic expression and, more so, use of drugs in decadent France, which, again, positions her as a subject who rebels for her own liberation. She is, as Yolanda Latorre (2005) calls her, "un arquetipo femenino de la decadencia" (p. 4) or, I would add, a modernist decadent femme fatale.

\subsection{Geopolitical Split and Afrancesamiento}

The geopolitics of the femme fatale, Espina, is of primary importance for understanding Pardo Bazán's geopolitical (split) feminism in this work. Besides Espina's beauty and attractiveness, which are "traditional" characteristics of the femme fatale repeated in this work, another crucial element that augments her seductiveness is French fashion: "El atractivo peculiar de esta mujer está en la ropa, en su habilidad de adaptarla al cuerpo, enroscar, ceñir y plegar la tela, incorporada, identificada a su persona" (Pardo Bazán, 1991, p. 345).

On a superficial level, Pardo-Bazán criticizes the imitation of French habits and the afrancesamiento $^{5}$ of Espina, whose fashionable and artistic taste and addictions are all related to French decadence and eventually lead her to death. As previously discussed, the imitation of French literature and customs was one of the elements assigned to Spanish women writers at the end of the nineteenth century and a main point of critique by male authors. Apparent reproach of the French habits in La Quimera seems to imply Pardo Bazán's compliance with male authors' criticism.

Espina is described as, "la cosmopolita Espina Porcel, hija de español y mexicana y residente

\footnotetext{
${ }^{4}$ Originate from male writers' works with femme fatale

${ }^{5}$ Luis Barbastro Gil (1993) explains that "afrancesamiento", the influence of France on the customs and common Spanish life, is a political matter, which evidences "la fragilidad del sistema político español a comienzos del siglo XIX, la hegemonía política de Francia en el concierto internacional de esta época y en la propia política interior española" (p. 8).
} 
en París" (Pardo Bazán, 1991, p. 97, emphasis added). Her origin and her afrancesamiento, as well as the fact that her seductive powers over men are most effective in France, make of her an Atlantic/French, but yet Spanish femme fatale who manipulates and destroys Spanish men in France. Her own decadence, taste in fashion and addictions are French, too. This makes her a split subject, trapped between Spain and France, colonialism and imperialism, as she is colonized by French habits, culture and decadence and, at the same time, she conquers and destroys Spanish men.

The complete influence of the French on Espina makes her a more non-Spanish than Spanish character. She is a mestizo, and this new mestizaje, represented through Espina, becomes threatening, as Mexico-Paris becomes a new form of modernity, which Spain cannot accomplish. In this way, Espina's mestizaje becomes a signifier of Spanish imperial crisis. In La Quimera, Spain is presented as a non-hegemonic and non-modern country; Spanish national identity is not confirmed, but rather subverted by embracing the anxieties of Spanish male writers and critics-the femme fatale-like influence of France on Spanish identity, an influence that cannot be resisted. Here Pardo Bazán shows the construction of hegemonic Occidentalism with France as its center, which, as commented by Joseba Gabilondo (2013), is something Spaniards cannot acknowledge without splitting the national Spanish subject: "[The Spanish nation] can only contemplate itself by invoking and annihilating the gaze directed at it by its others" (p. 86).

Hence, Pardo Bazán's seeming critique of modernity and French decadence is superficial and has a feminist purpose. She employs afrancesamiento to introduce the geopolitical split (Spain/France/Mexico) in the novel-the split of her feminist subject, Espina, which has a liberating effect. A foreign place (France) is a space of liberation and the environment where Espina is identified as a feminist subject. The superficial critique of afrancesamiento is a sign of Pardo Bazán's strategic use of the most important criticism of male writers and critics against women writers. In this way, Pardo Bazán does the ultimate Butlerian performance or mimicry of this most hegemonic masculine discourse.

This positioning of France as a model of promising modernity that can change the status quo, reflects Pardo Bazán's personal quest for feminist models in European literature, which eventually made possible her formation as "transnational subject that defies any nationalist understanding of literature" (Gabilondo, 2013, p. 263). At the same time, this reflects the affirmation of French cultural and political superiority over Spain, which is a new form of colonization of the Spanish exempire. Thus, Pardo Bazán uses the foreign to criticize the canonical understanding of Spanish literature, culture and identity. In this novel, Pardo Bazán performs the ultimate fantasy and trauma of Spanish masculine culture and identity, the one of being destroyed by a Latin American/French woman. This sadism is, ultimately, Pardo Bazán's feminist response to Spanish male writers/critics' "violence" against her.

\section{Failure of Domesticity and Crisis of Masculinity}

The main protagonist of La Quimera is Silvio Lago, a young, poor, bohemian artist and dreamer who is unsuccessful in establishing himself as painter in patriarchal Spain. He is also the main "victim" of Espina, who reveals to him in Paris "un nuevo ámbito de estilo, sensibilidad y arte, "ultramodernista y decadente"' (Pardo Bazán, 1991, p. 97). The lovers meet in Spain, but soon leave together to France, where Espina promises to help Silvio succeed as an artist, but instead manipulates him and, eventually, destroys him. Other important characters in the work are Minia Dumbria, Valdivia and Clara. Minia is Silvio's friend and a traditional, religious Spanish woman who offers him sanctuary after his misfortunes in Paris. Minia eventually serves as Pardo Bazán's double in the narrative. Valdivia, as already mentioned earlier, is Espina's Brazilian boyfriend, whom she also manipulates in Paris. Finally, Clara is the innocent and beautiful ángel del hogar who wants to marry Silvio and offers him her love and family fortune, but whom Silvio rejects due to his misogynism and obsession with a foreign, artificial, and even perverse fatal woman.

In the first part of the novel, before his infatuation with Espina, Silvio is described as indifferent to and disgusted by women, as he feels "el instintivo desprecio hacia la mujer que se le rinde" (Pardo Bazán, 1991, p. 210). This augments the importance of his change of position and complete 
obsession with Espina. Silvio's attitude towards marriage and women is also expressed through his relationship with Clara, the counterpart (ángel del hogar-femme fatale) of Espina Poncel in the work. Silvio rejects both Clara's love and the family fortune she is willing to give him to help achieve his artistic dreams, attributing this rejection to his inability to love a regular woman and the boredom that women in general provoke in him:

Serías infeliz tú y más infeliz yo. A los ocho días, ¿sabes?, viviendo con ella, viéndola peinarse, comer, toser, no hay mujer que no me hastíe. ¿Digo hastío? Aborrecimiento. [...] No me conoces. Soy muy bárbaro, mucho. Además, estoy embrujado. Sólo existo para mis sueños. (Pardo Bazán, 1991, p, 240)

For Silvio, feminine attractiveness is something opposite to the domestic and warm security offered by Clara. According to Kirkpatrick, the disdain that Silvio expresses towards women is a consequence of his effort to negate his dependence on them (p. 102). Silvio, a decadent artist and a dandy, depends on women such as Espina, Minia or his customers/models in existential, financial and professional ways. This feminizes Silvio and domesticizes him as "mientras más lucha por liberarse de su dependencia de las mujeres como fuente de apoyo, estatus e identidad, más vacío e inseguro se siente" (Kirkpatrick, 2003, p. 102).

Silvio's feminization in the novel is also strategic, as it reflects Spanish masculinity in crisis caused by imperial loss. At the same time, it serves as a representation of domesticity and patriarchy as the main causes of the prolongation of the loss of masculine hegemony and primary obstacles for the modernization of Spain. All the women that Silvio depends on, and Spanish women of the period in general, gain wealth through their fathers or husbands/lovers. They are impeded from gaining it independently. Silvio, at the same time, cannot survive as a modern dandy or become an independent and successful artist in patriarchal Spain without these women's money. In this way, La Quimera indicates that the status quo is untenable and therefore modernization of Spain is necessary.

Knowing Pardo Bazán's feminist orientation and agenda, it is safe to say that she invites such change to achieve, above all, feminine emancipation. This is because women were still oppressed by patriarchy and domesticity and had no other solution but rebelling against them. The main example is Espina and her transgression of patriarchal norms. This is why, in accordance with Virginia Woolf's (1942) famous words about angel de hogar: "Had I not killed her she would have killed me" (p. 238), Pardo Bazán openly defeats the ideal of domesticity, ángel del hogar. After Silvio's rejection, Clara, "the good woman of the work", goes to a convent, disappointed in love and humans and unable to comply with social expectations.

The principal male character of the novel rejects the ideal domestic Spanish woman as noninteresting and outright boring and instead becomes obsessed with a rich, decadent, French/Mexican woman who challenges and transgresses domesticity. This is again a geopolitical space, as Clara, ángel del hogar, is quintessentially Spanish and Espina, the femme fatale, is Atlantic, French, rich and decadent. Espina represents modernity, whereas Clara and Spain are depicted as non-modern and traditional. Espina is fatal and unattainable, dangerous and irresistible and a major source of artistic inspiration for Silvio: "Desde que he visto a Espina, se me descubre la mujer moderna, la Eva inspiradora de infinitas direcciones artísticas, agudamente contemporáneas" (Pardo Bazán, 1991, p. 337). Silvio chooses France over Spain, unknown danger over domestic security and, most importantly, modernity over non-modernity. This confirms Phoebe Porter's (1987) observation that in Pardo Bazán's works with femmes fatales the characterization of the idealized domestic women "pales before that of the principal female characters who are all beautiful, sensual and erotically dangerous" (p. 263).

\section{Pardo Bazán's Traditional/Modern Split}

Espina's imperialism is liberating for the female character and a vivid reminder of the lack of power of Spanish masculinity. At the end, Espina destroys Silvio's dreams and he, sick and defeated, goes back to Spain, to his hometown. A Christian woman, artist Minia, who, according to López 
(1979), expresses Pardo Bazán's religious viewpoints, helps him get back to reality and recognize his craziness: "Al lado de la caritativa señora el joven pintor comprende al fin la vida y reconoce la locura de su quijotismo, llegando a la resignación ante el destino y a la aceptación de su identidad propia como don Quijote" (p. 64).

This ending of Pardo Bazán's main protagonist makes sense, if we remember that Pardo Bazán was a devoted Catholic. Silvio's healing is through faith and religion and this, according to López, reflects Pardo Bazán's own personal convictions which position her as both "la Cristiana sincera y la pensadora moderna" (p. 69). It can be concluded that Pardo Bazán does not accept modernity in its entirety, but that she is progressive in her way of thinking, especially regarding the position of women in the patriarchal society.

Several critics also point out reflections of Pardo Bazán's personal ideas through some of $L a$ Quimera's characters. Pattison (1971) observes that Pardo Bazán appears in the work in two ways-as Christian woman Minia and in that "the artistic conversion of Silvio Lago from strict naturalism to an idealistic, religious realism is the history of Doña Emilia's own development" ( $p$. 87). Gonzáles-Arias also comments that Silvio's proceeding from costumbrismo to spiritualism represents the "author's own trajectory from early naturalistic and regionalist concerns to the treatment in her last novels of the themes of fin-de-siècle and early twentieth-century literary currents-Decadentism, Symbolism and Modernism" (p. 150). However, I argue that the appearance of Pardo Bazán's personal voice is not limited to only those two characters. Even though Pardo Bazán eventually condemns Espina and her way of living opposed to Christian values, Pardo Bazán expresses her feminist ideas through this character.

\subsection{Failure of the Feminist Cause}

Despite the expression of feminist sentiment, this work confirms the limits of Pardo Bazán's feminism in Spain, as Espina, even though liberated from the constraints of Spanish patriarchy through French decadentism, still dies at the end. Pardo Bazán liberates her femme fatale from male influence through both geopolitical split and non-geopolitical spaces (art, drugs, death), but this ultimately puts an end to her (feminist) existence.

Espina's self-destructiveness and drug addiction eventually lead her to death and this resolves the tension between modernity and non-modernity in the novel. With Espina's death, Pardo Bazán's geopolitical solution for female liberation (France) ends up as an impossible solution. With it, it becomes clear that Pardo Bazán does not promote reckless female behavior or accept all the elements of modernity, but that she does advocate for some changes in the status quo: improvements of the social position of women have to be made, as the ideal of ángel del hogar is too destructive for the entire society and nation. As Porter (1987) observes, with Espina, Pardo Bazán presents a moral degeneration, which is a result of an extreme aestheticism, and she condemns it, but at the same time understands it (p. 266).

The point about Pardo Bazán's simultaneous condemnation and understanding of Espina's extreme aestheticism is fundamental for Espina's liberation from patriarchal norms and expression of the author's feminist ideas. Pardo Bazán might condemn the destructiveness and superficiality of a modernist femme fatale's exaggerated aestheticism, but understands it is the only reasonable response to deluded patriarchal norms that perpetuate an untenable domestic ideal. Repression causes transgression, mirrored by Espina's addictions, superficiality and perfidy. Pardo Bazán uses the exaggerated aestheticism of her character, typically reserved for male characters, to equalize Espina with men and represent her as a subject.

\section{Conclusion}

In conclusion, Espina is punished at the end, just like femmes fatales in male authors' works. In contrast to the femmes fatales in male author's works, she remains a subject even in her own destruction and she is never dominated by men. Pardo Bazán liberates her femme fatale through the geopolitical split between Spain/France and establishes Paris as Espina's place of freedom, where she conquers and destroys Spanish men. However, Paris as a geopolitical solution fails, as 
Espina dies at the end. Death is the final non-geopolitical space that Pardo Bazán creates for the liberation of her femme fatale from the influence of patriarchy and men, besides art, drugs and decadence. Nonetheless, Espina's final non-geopolitical space of freedom, death, ends her physical existence as feminist subject. Such an ending testifies to the crisis of Pardo Bazán's feminism in Spain, which culminates with her novel Dulce dueño.

\section{References}

Allen, V. M. (2000). The Femme Fatale: A Study of the Early Development of the Concept in Mid - Nineteenth Century Poetry and Painting. Ann Arbor, MI: UMI Dissertation Services.

Barbastro Gil, L. (1993). Los afrancesados: primera emigración política del siglo XIX español (1813-1820). Madrid: CSIC.

Baynat Monreal, E. (2007). El poder de la palabra y la mirada en Carmen de Mérimée. Anales de filología francesa, 15, 43-58.

Blanco, A. (1995). Gender and National Identity: The Novel in Nineteenth-Century Spanish Literary History. In: L. Charnon-Deutsch \& J. Labanyi (Eds.), Culture and Gender in Nineteenth-Century Spain (pp. 120-136). Oxford: Oxford UP.

Doane, M. A. (1991). Femmes Fatales: Feminism, Film Theory, Psychoanalysis. New York: Routledge.

Felski, R. (2003). Literature after Feminism. Chicago: University of Chicago Press.

Gabilondo, J. (2008). On the Inception of Western Sex as Orientalist Theme Park: Tourism and Desire in Nineteenth-Century Spain (Carmen, Don Juan). In: E. Afinoguenova \& J. Martí Olivella (Eds.), Spain is Different: Tourist Locations, Attractions, and Discourses in Modern Spanish Culture (pp. 19-26). New York: Lexington Books.

----. (2009). Towards a Postnational History of Galician Literature: On Pardo Bazán's Transnational and Translational Position. The Bulletin of Hispanic Studies, 86.2, 249-269.

----. (2013). On the Spanish Primal Scene: The Double Gaze of Orientalism and Occidentalism in Andalusian and Basque Cinema. In: T. Pavlovic \& J. Labanyi (Eds.), Companion to Spanish Cinema (pp. 85-98). New York: Blackwell.

Gómez de Baquero, E. (1926). De Gallardo a Unamuno. Madrid: Talleres Espasa-Calpe, s.a.

González-Arias, F. (1922). Portrait of a Woman as Artist: Emilia Pardo Bazán and the Modern Novel in France and Spain. New York: Garland Pub.

Grossman, J. (2009). Rethinking the Femme Fatale in Film Noir: Ready for Her Close-Up. New York: Palgrave Macmillan.

Hanson, H., \& O' Rawe, C. (2010). The Femme Fatale: Images, Histories, Contexts. Basingstoke: Palgrave Macmillan.

Kirkpatrick, S. (2003). Mujer, modernismo y vanguardia en España: 1898-1931. Madrid: Cátedra.

Latorre, Y. (2005). Decadentes y diletantes: La mujer en la última Pardo Bazán. In: V. Trueba, E. Rubio, P. Miret, L.F. Díaz Larios, J.F. Botrel \& L. Bonet (Eds.), Sociedad de Literatura Española del Siglo XIX. III Coloquio: Lectora, Heroína, Autora (La mujer en la literatura española del siglo XIX) (Barcelona, 23-25 de Octubre de 2002) (pp. 195-202). Barcelona: Universitat de Barcelona, PPU.

López, M. (1979). Moral y estética de fin de siglo en La quimera de Pardo Bazán. Hispania 62, 62-70.

López Trigal, L., \& Del Pozo. P. B. (1999). Geografía política. Madrid: Cátedra.

Mérimée, P. (1846). Carmen. Liège: G. Thone.

Osborne, R. E. (1964). Emilia Pardo Bazán: Su vida y sus obras. 42 Vol. México: Ediciones de Andrea.

Pardo Bazán, E., \& Mayoral, M. La Quimera. (1991). 336. Vol. Madrid: Cátedra.

Pattison, W. T. (1971). Emilia Pardo Bazán. TWAS 134: Spain Vol. New York: Twayne Publishers.

Porter, P. (1987). The Femme Fatale: Emilia Pardo Bazán's Portrayal of Evil and Fascinating Women. In: G. Paolini (Ed.), LA CHISPA'87: Selected Proceedings (pp. 263-70). New Orleans: Tulane U.

Said, E. W. (1978). Orientalism. New York: Pantheon Books.

Scanlon, G. M. (1976). La polémica feminista en la España contemporánea (1868-1974). México: Siglo XXI.

----. (1995). Gender and Journalism: Pardo Bazán's Nuevo Teatro Crítico. In: L. Charnon-Deutsch \& J. Labanyi (Eds.), Culture and Gender in Nineteenth-Century Spain (pp. 230-49). Oxford: Clarendon Press.

Stott, R. (1992). The Fabrication of the Late-Victorian Femme Fatale: The Kiss of Death. Basingstoke: Macmillan.

Valis, N. (1995). Autobiography as Insult. In: L. Charnon-Deutsch \& J. Labanyi (Eds.), Culture and Gender in Nineteenth-Century Spain (pp. 27-52). Oxford: Clarendon Press.

Valle-Inclán, R. (1965). Sonata de primavera, Sonata de estío: Memorias del marqués de Bradomín. Madrid: Espasa-Calpe.

Wood, J. (1990). Images of Feminine Evil in Emilia Pardo Bazán's La Quimera. Romance Quarterly, 37.3, 33743. 
Woolf, V. (1942). Professions for women. In: V. Woolf, The Death of the Moth and other Essays (pp. 235-42). Orlando: Harcourt Brace. 